\title{
Polyborate anions templated by cationic transition-metal complexes:
}

\author{
Altahan, Mohammed; Beckett, Michael; Coles, Simon J.; Horton, Peter N.
}

\section{Phosphorus, Sulfur and Silicon and the Related Elements}

\author{
DOI: \\ 10.1080/10426507.2015.1128907 \\ Published: 01/04/2016 \\ Peer reviewed version \\ Cyswllt i'r cyhoeddiad / Link to publication
}

Dyfyniad o'r fersiwn a gyhoeddwyd / Citation for published version (APA):

Altahan, M., Beckett, M., Coles, S. J., \& Horton, P. N. (2016). Polyborate anions templated by cationic transition-metal complexes: [Co(diNOsar)]2[B3O3(OH)4]Cl5.4.75 H2O. Phosphorus, Sulfur and Silicon and the Related Elements, 191(4), 572-575.

https://doi.org/10.1080/10426507.2015.1128907

\footnotetext{
Hawliau Cyffredinol / General rights

Copyright and moral rights for the publications made accessible in the public portal are retained by the authors and/or other copyright owners and it is a condition of accessing publications that users recognise and abide by the legal requirements associated with these rights.

- Users may download and print one copy of any publication from the public portal for the purpose of private study or research.

- You may not further distribute the material or use it for any profit-making activity or commercial gain

- You may freely distribute the URL identifying the publication in the public portal ?
}

Take down policy

If you believe that this document breaches copyright please contact us providing details, and we will remove access to the work immediately and investigate your claim. 


\title{
Polyborate anions templated by cationic transition-metal complexes: [Co(diNOsar] $]_{2}\left[\mathrm{~B}_{3} \mathrm{O}_{3}(\mathrm{OH}]_{4}\right] \mathrm{Cl}_{5} \cdot 4.75 \mathrm{H}_{2} \mathrm{O}$
}

\author{
Mohammed A. Altahan', Michael A. Beckett ${ }^{1 *}$, Simon J. Coles ${ }^{2}$, Peter N. Horton ${ }^{2}$ \\ ${ }^{1}$ School of Chemistry, Bangor University, Bangor, Gwynedd, LL57 2UW, UK \\ ${ }^{2}$ School of Chemistry, Southampton University, Southampton, SO17 1BG, UK
}

GRAPHICAL ABSTRACT

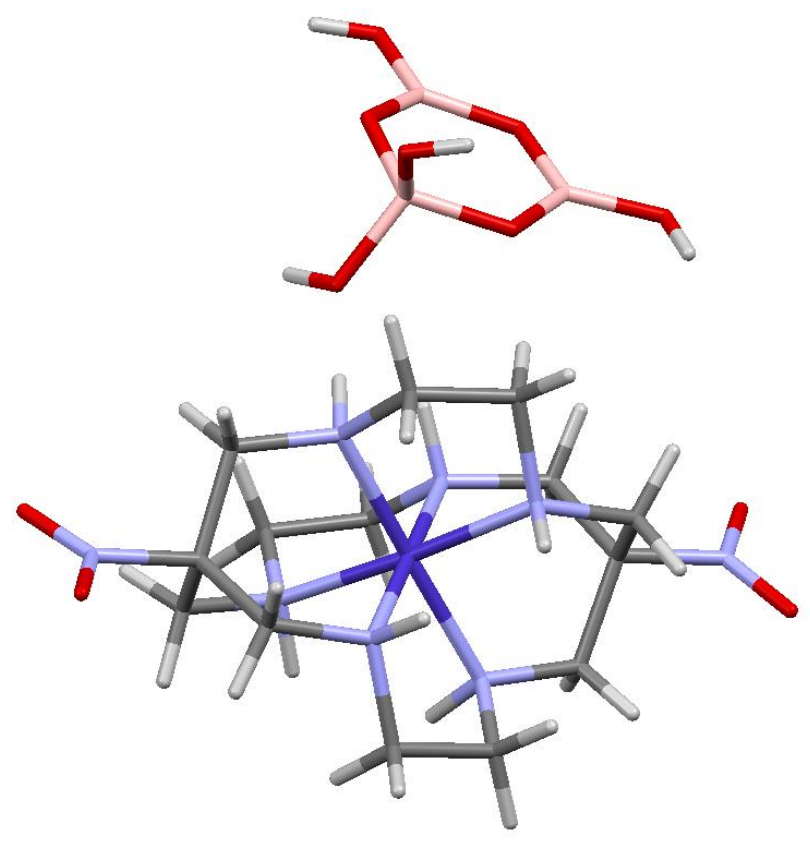

Abstract The transition metal complexes $[\mathrm{Co}(\text { diNOsar })]^{3+},\left[\mathrm{Co}(\text { en })_{3}\right]^{3+},\left[\mathrm{Co}(\text { dien })_{2}\right]^{3+}$ have been used to template unusual isolated polyborate anions by reaction of basic aqueous solutions containing the cations with $\mathrm{B}(\mathrm{OH})_{3}(1: 10)$. The synthesis and

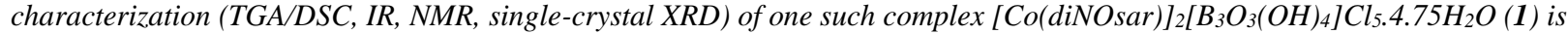
reported. Compound 1 is a rare example of a salt containing the isolated triborate(1-) anion, and its formation is engineered by the cation, which has extensive H-bond interactions with the anion in its secondary coordination sphere.

Keywords Triborate(1-); Self-assembly; H-bonds; [Co(diNOsar) $]^{3+}$; X-ray Structure; Oxidoborate

Received xx yyyy 2015; accepted xx yyyy 2015

Acknowledgements: We thank the EPSRC for use of the NCS Service.

Address correspondence to Dr M.A. Beckett, School of Chemistry, Bangor University, Bangor, Gwynedd, UK.

Email: m.a.beckett@bangor.ac.uk

Electronic supplementary information (ESI) available. CCDC 1423520. This data can be obtained free of charge from the Cambridge

Crystallographic Data Centre via www.ccdc.cam.ac.uk/data_request/cif. 


\section{INTRODUCTION}

Polyborate anions are conveniently classified ${ }^{1}$ as either polymeric (2D or 3D chains, sheets or networks) or discrete 'isolated' anionic moieties. Isolated polyborate anions are readily synthesized by the addition of $\mathrm{B}(\mathrm{OH})_{3}$ to a basic aqueous solution containing templating cations $^{2}$, or by solvothermic ${ }^{3}$ methods. Templated products arise since $\mathrm{B}(\mathrm{OH})_{3}$ in basic aqueous solution exists as a dynamic combinatorial library of polyborate anions ${ }^{4}$. In general, pentaborate(1-) salts (containing the $\left[\mathrm{B}_{5} \mathrm{O}_{6}(\mathrm{OH})_{4}\right]^{-}$anion) are formed because these salts have a strong H-bonded anionic lattice, which is sufficiently flexible to accommodate many medium sized cations ${ }^{5}$. Salts containing polyborate anions other than pentaborate(1-) are relatively rare $^{6}$. We are interested in the synthesis of structurally novel polyborate anions and have adopted a strategy of templating such species by the use of sterically demanding and/or highly charged cations $^{7,8}$. Herein, we report the synthesis of several salts containing isolated polyborate anions partnered with transition metal cations and describe in detail the synthesis and characterization of the salt $[\mathrm{Co}(\text { diNOsar })]_{2}\left[\mathrm{~B}_{3} \mathrm{O}_{3}(\mathrm{OH})_{4}\right] \mathrm{Cl}_{5} \cdot 4.75 \mathrm{H}_{2} \mathrm{O}(\mathbf{1})$ which contains the isolated triborate $(1-)$ anion.

\section{RESULTS AND DISCUSSION}

\section{Synthesis}

Halide salts of transition-metal complexes are readily transformed, provided they are stable in basic solution, into their hydroxide salts by use of a Dowex 550A hydroxide activated anion exchange resin. The resulting aqueous solutions, which are separated from the resin, were reacted with $\mathrm{MeOH} / \mathrm{H}_{2} \mathrm{O}$ solutions of $\mathrm{B}(\mathrm{OH})_{3}(1: 10)$ to afford polyborate anions salts of cationic transition-metal complexes. Several salts have been prepared e.g.

$\left[\mathrm{Co}(\text { diNOsar) }]_{2}\left[\mathrm{~B}_{3} \mathrm{O}_{3}(\mathrm{OH})_{4}\right] \mathrm{Cl}_{5} \cdot 4.75 \mathrm{H}_{2} \mathrm{O}(\mathbf{1}),\left[\mathrm{Co}(\mathrm{en})_{3}\right]\left[\mathrm{B}_{5} \mathrm{O}_{6}(\mathrm{OH})_{4}\right]\left[\mathrm{B}_{8} \mathrm{O}_{10}(\mathrm{OH})_{6}\right] \cdot 5 \mathrm{H}_{2} \mathrm{O}(\mathbf{2}), s-\right.$ fac- $\left[\mathrm{Co}(\text { dien })_{2}\right]\left[\mathrm{B}_{7} \mathrm{O}_{9}(\mathrm{OH})_{6}\right] \cdot 9 \mathrm{H}_{2} \mathrm{O}(\mathbf{3})$. Compounds 2 and 3, which contain previously unobserved octaborate(2-) and heptaborate(3-) anions, were prepared in reasonable yields $(\sim 40 \%)$ and details ${ }^{7,8}$ of their synthesis and full characterization can be found elsewhere. The starting complex $\left[\mathrm{Co}(\right.$ diNOsar) $] \mathrm{Cl}_{3}$ was prepared by a reported ${ }^{9}$ procedure for the synthesis of $\mathbf{1}$. Compound 1 was isolated in low yield (10\%) and its high chloride content would indicate that 
Phosphorus, Sulfur and Silicon, 190: xxxx-yyyy, 2015

the ion exchange was not completely successful in this case. Nevertheless, we were able to characterize $^{10}$ the compound by elemental analysis, mpt, thermally (TGA/DSC) and by NMR $\left({ }^{1} \mathrm{H},{ }^{13} \mathrm{C},{ }^{11} \mathrm{~B}\right)$ and IR spectroscopy. Single-crystals were also suitable for a XRD study.

NMR spectra of $\mathbf{1}$ were obtained in $\mathrm{D}_{2} \mathrm{O}$. The ${ }^{1} \mathrm{H}$ NMR spectrum of $\mathbf{1}$ consists of $\mathrm{AB}$ doublets for the $\mathrm{CH}_{2}$ groups of the capping units and a complex AA'BB' pattern ${ }^{11}$ (looking like a doublet with $J=9.2 \mathrm{~Hz}$ ) for the $\mathrm{CH}_{2}$ protons of the ethylenediamine rings. The secondary amine protons are observed with the residual HOD signal at $\delta=4.70 \mathrm{ppm}$. The ${ }^{13} \mathrm{C}\left\{{ }^{1} \mathrm{H}\right\}$ spectrum shows the expected 3 signals at $\delta=51.4$ (ethylene diamine groups), $\delta=55.1\left(\mathrm{CH}_{2}\right.$ of capping groups) and $\delta=87.8 \mathrm{ppm}$ (tertiary $\mathrm{C}-\mathrm{NO}_{2}$ cap). As a consequence of boron exchange associated with rapid $\mathrm{B}(\mathrm{OH})_{3} /\left[\mathrm{B}(\mathrm{OH})_{4}\right]^{-/} /$polyborate equilibria ${ }^{4}$ the ${ }^{11} \mathrm{~B}$ spectrum shows just one signal at $\delta=$ $+16.2 \mathrm{ppm}$.

Thermal (TGA) analysis in air was consistent with a three step process involving low temperature $\left(<125^{\circ} \mathrm{C}\right)$ loss of water of crystallization, further dehydration to form an anhydrous polyborate $\left(200-275^{\circ} \mathrm{C}\right)$, and oxidation of organics $\left(275-800^{\circ} \mathrm{C}\right)$ to leave a glassy inorganic residue of composition $\mathrm{Co}_{2} \mathrm{~B}_{3} \mathrm{O}_{5} \mathrm{Cl}_{5}$. Such thermal decomposition has been previously observed ${ }^{12}$ for transition-metal polyborate salts.

\section{X-ray structure of $\left[\mathrm{Co}(\mathrm{diNOsar}]_{2}\left[\mathrm{~B}_{3} \mathrm{O}_{3}(\mathrm{OH}]_{4}\right] \mathrm{Cl}_{5} \cdot 4.75 \mathrm{H}_{2} \mathrm{O}\right.$}

Full crystallographic data for $\mathbf{1}$ are available in the supplementary information ${ }^{13}$ and crystallographic data are summarized in a footnote ${ }^{14}$. Compound $\mathbf{1}$ is an ionic compound and is a rare example of a salt containing the triborate(1-) anion. In addition to the $\left[\mathrm{B}_{3} \mathrm{O}_{3}(\mathrm{OH})_{4}\right]^{-}$anion, 1 contains 2 independent [Co(diNOsar) $]^{3+}$ cations, $5 \mathrm{Cl}^{-}$anions and $4.75 \mathrm{H}_{2} \mathrm{O}$ molecules. There is a disordered water within the asymmetric unit. One area can exist as either one (25\%) or two (75\%) molecules of water, hence the fractional formula. Atomic labelling for the triborate(1-) anion is shown in Figure 1.

The $[\mathrm{Co}(\text { diNOsar })]^{3+}$ cation comprises a central $\mathrm{Co}^{3+}$ ion surrounded by the $6 \mathrm{~N}$ donor atoms of the hexadentate neutral 'diNOsar' ligand in a distorted octahedral environment. Cis and trans $\mathrm{N}-\mathrm{Co}-\mathrm{N}$ angles range from $86.43(9)-92.58(9)^{\circ}\left(\right.$ av. $\left.90.06^{\circ}\right)$ and $175.79(9)-178.12(10)^{\circ}$ 
Phosphorus, Sulfur and Silicon, 190: xxxx-yyyy, 2015

(av. 176.62 ${ }^{\circ}$ ) respectively. The Co-N bond lengths range from 1.963(2) - 1.975(2) $\AA$, av. 1.969 $\AA$. These data are not significantly different from previously reported data ${ }^{15}$ for this cation.

The $\left[\mathrm{B}_{3} \mathrm{O}_{3}(\mathrm{OH})_{4}\right]^{-}$ion of 1 possesses a $\mathrm{B}_{3} \mathrm{O}_{3}$ (boroxole) ring with one 4-coordinate and two 3-coordinate B centres. B-O bond lengths to 3-coordinate (B2 and B3) and 4-coordinate (B1) B centres range from 1.347(4) - 1.386(4) $\AA$ (av. $1.363 \AA$ ) and 1.466(4) - 1.471(4) $\AA$ (av. $1.488 \AA$ A), respectively. B2-O1 (1.351(3) Å) and B3-O3 (1.347(4) Å) are significantly shorter than the other B-O bonds within the boroxole rings. The boroxole ring is planar with ring angles ranging from $112.3(2)-122.4(2)^{\circ}$. The smallest ring angle $(\mathrm{O} 1 \mathrm{~B} 1 \mathrm{O} 3)$ involves the 4-coordinate $\mathrm{B}$ centre, whereas ring angles at $\mathrm{O} 1, \mathrm{O} 2$, and $\mathrm{O} 3$ average $121.1^{\circ}$ and those at the 3 - coordinate $\mathrm{B}$ centres (B2 and B3) average 121.6 . This pattern of bond angles and bond lengths are in accord with previously reported data for this anion ${ }^{16}$ and mirror corresponding data observed ${ }^{17}$ in related isoelectronic systems such as $\mathrm{Ar}_{3} \mathrm{~B}_{3} \mathrm{O}_{3} \cdot \mathrm{L}$ and $\left[\mathrm{Ph}_{3} \mathrm{~B}_{3} \mathrm{O}_{3} \cdot(\mathrm{OH})\right]^{-}$.

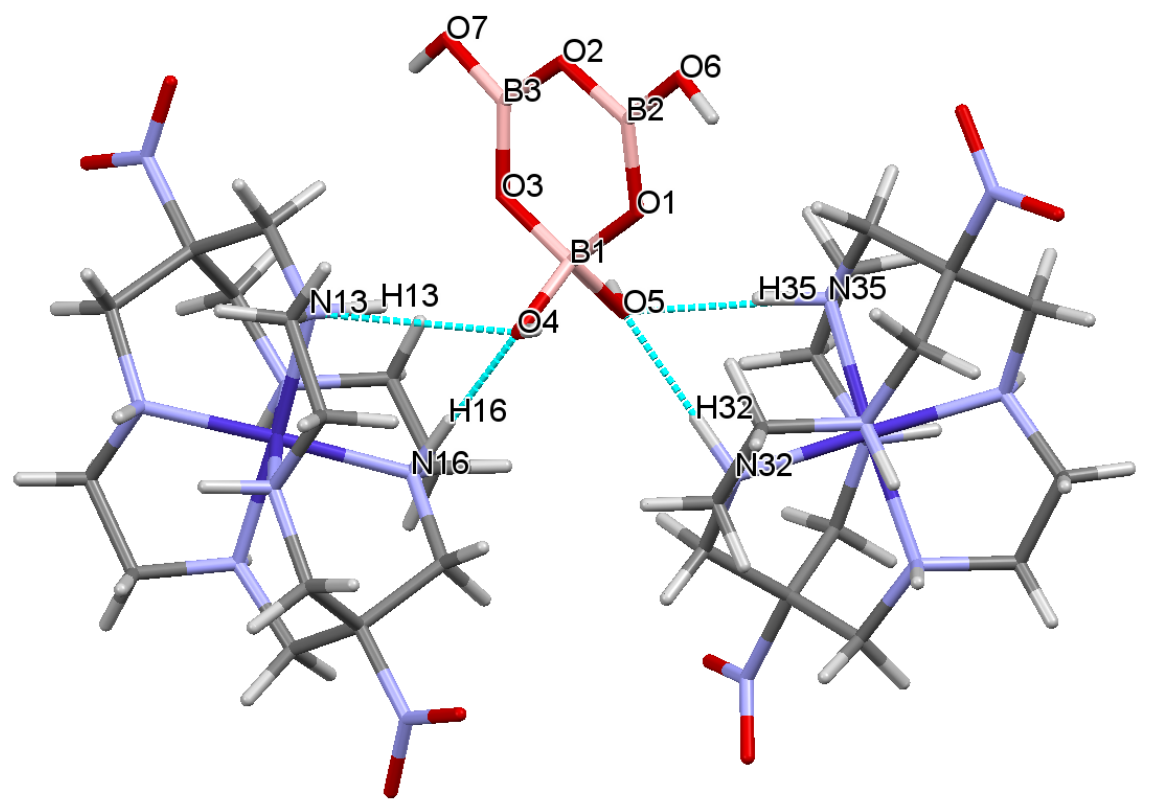

Figure 1 Cation-triborate H-bond interactions in 1. $d(\mathrm{~N} 13-\mathrm{H} 13) 1.00 \AA, d(\mathrm{H} 13 \cdots \mathrm{O} 4) 1.98 \AA, d(\mathrm{~N} 13 \cdots \mathrm{O} 4) 2.935(3)$ $\AA,<(\mathrm{N} 13 \mathrm{H} 13 \mathrm{O} 4) 159.2^{\circ} ; d(\mathrm{~N} 16-\mathrm{H} 16) 1.00 \AA$, $d(\mathrm{H} 16 \cdots \mathrm{O} 4) 1.73 \AA, d(\mathrm{~N} 16 \cdots \mathrm{O} 4) 2.731(3) \AA$ $d(\mathrm{~N} 32 \mathrm{H} 32) 1.00 \AA, d(\mathrm{H} 32 \cdots \mathrm{O} 5) 1.81 \AA, d(\mathrm{~N} 32 \cdots \mathrm{O} 5) 2.810(3) \AA$, < (N32H32O5) $175.8^{\circ} ; d(\mathrm{~N} 35-\mathrm{H} 35) 1.00 \AA$, $d(\mathrm{H} 35 \cdots \mathrm{O} 5) 1.93 \AA, d(\mathrm{~N} 35 \cdots \mathrm{O} 5) 1.93 \AA, d(\mathrm{~N} 35 \cdots \mathrm{O} 5) 2.898(3) \AA$, <(N35H35O5) $163.4^{\circ}$.

Received xx yyyy 2015; accepted xx yyyy 2015

Acknowledgements: We thank the EPSRC for use of the NCS Service.

Address correspondence to Dr M.A. Beckett, School of Chemistry, Bangor University, Bangor, Gwynedd, UK.

Email: m.a.beckett@bangor.ac.uk

Electronic supplementary information (ESI) available. CCDC 1423520. This data can be obtained free of charge from the Cambridge Crystallographic Data Centre via www.ccdc.cam.ac.uk/data_request/cif. 
Phosphorus, Sulfur and Silicon, 190: xxxx-yyyy, 2015

There are multiple H-bond interactions within the solid-state structure of $\mathbf{1}$. Full details can be found in the supplementary information. Polyborate anions usually display multiple anion-anion $\mathrm{H}$-bond interactions and these are believed ${ }^{5}$ to be the driving force in the synthesis of non-metal cation pentaborate(1-) salts. Anion-anion interactions were found to be present in 2 and 3. However, in 1, triborate-triborate H-bond interactions are absent and each triborate(1-) anion is isolated from others by $\mathrm{H}_{2} \mathrm{O}$ bridges, forming a sheet-like structure (Figure 2). This isolation implies that the crystal structure of $\mathbf{1}$ is engineered by interactions with other components within the system. The triborate(1-) anion is able to form 4 donor H-bonds and has 7 potential H-bond acceptor sites. The triborate(1-) anion in $\mathbf{1}$ does indeed form 4 donor interactions: three to $\mathrm{H}_{2} \mathrm{O}$ molecules and one to a $\mathrm{Cl}^{-}$anion $(\mathrm{O} 6 \mathrm{H} 6 \cdots \mathrm{Cl} 2)$. The triborate(1-) anion accepts $2 \mathrm{H}$-bonds at each hydroxyl group (O4 and $\mathrm{O5}$ ) on the 4-coordinate B1, and also at $\mathrm{O} 6$ from $\mathrm{H}_{2} \mathrm{O}(\mathrm{O} 54-\mathrm{H} 54 \cdots \mathrm{O} 6)$. The $\mathrm{H}$-bonds directed at $\mathrm{O} 4$ and $\mathrm{O} 5$ originate from amine hydrogens on two $[\mathrm{Co}(\text { diNOsar })]^{3+}$ cations in a chelating mode, as illustrated in Figure 1. These H-bond interactions are likely to be responsible for templating this salt and assembling the triborate(1-) anion. Secondary amine hydrogens of $\left[\mathrm{Co}(\mathrm{diNO} \text { sar }]^{3+}\right.$ are known ${ }^{15}$ to form similar H-bond interactions e.g. $[\mathrm{Co}($ diNOsar $)]\left[\mathrm{S}_{2} \mathrm{CN}\left(\mathrm{CH}_{2}\right)_{4}\right]_{3}$.

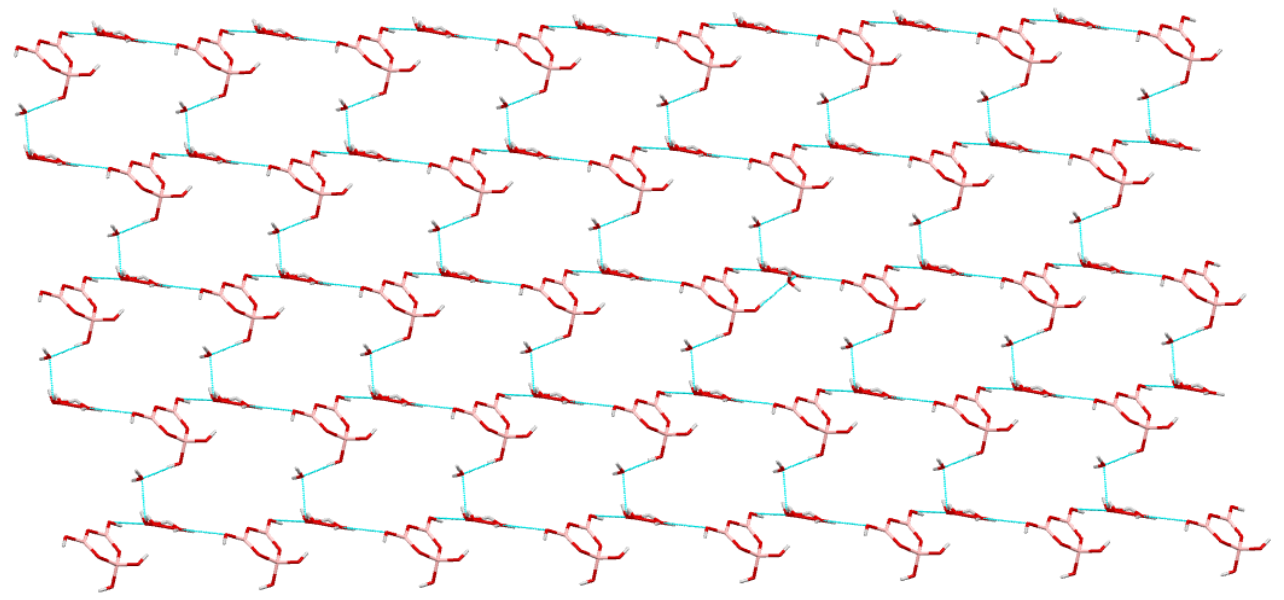

Figure 2 The triborate(1-) anions are arranged in planes linked together by $\mathrm{H}$-bonds from $\mathrm{H}_{2} \mathrm{O}$ molecules. The $[\mathrm{Co}(\text { diNOsar })]^{3+}$ cations fill the cavities and H-bond to the triborate(1-) anions.

Received xx yyyy 2015; accepted xx yyyy 2015

Acknowledgements: We thank the EPSRC for use of the NCS Service.

Address correspondence to Dr M.A. Beckett, School of Chemistry, Bangor University, Bangor, Gwynedd, UK.

Email: m.a.beckett@bangor.ac.uk

Electronic supplementary information (ESI) available. CCDC 1423520. This data can be obtained free of charge from the Cambridge Crystallographic Data Centre via www.ccdc.cam.ac.uk/data_request/cif. 
Phosphorus, Sulfur and Silicon, 190: xxxx-yyyy, 2015

Copyright $($ Taylor and Francis Group, LLC

ISSN: 1042-6507 print / 1563-5325 online

DOI: $10.1800 / 10426507.2015$

\section{Summary}

$[\mathrm{Co}(\text { diNOsar })]_{2}\left[\mathrm{~B}_{3} \mathrm{O}_{3}(\mathrm{OH})_{4}\right] \mathrm{Cl}_{5} .4 .75 \mathrm{H}_{2} \mathrm{O}$ is a rare example of a salt containing the isolated triborate(1-) anion. It has been obtained from a self-assembly reaction of (partially) $\mathrm{OH}^{-}$ exchanged aqueous solution of $[\mathrm{Co}($ diNOsar $)] \mathrm{Cl}_{3}$ with $\mathrm{B}(\mathrm{OH})_{3}(1: 10)$. The solid-state structure of 1 shows the anion in the secondary coordination sphere of the cation. There are strong cationanion H-bond interactions, which help to engineer the formation of the triborate(1-) anion.

\section{REFERENCES}

1. (a) Christ, C.L.; Clarke, J.R. Phys Chem. Miner, 1977, 2, 59-87; (b) Schubert, D.M.; Smith, R.A.; Visi, M.Z. Glass Technol. 2003, 44, 63-70.

2. Beckett, M.A.; Horton, P.N.; Coles, S.J.; Martin, D.W. Inorg. Chem., 2011, 50, 12215-12218.

3. (a) Wang, G.-M.; Pan, C.-Y.; Zheng, S.-T.; Yang, G.-Y. Acta Cryst. 2007, E63, o1104-o1105; (b) Wang, G.-M.; Sun Y.-Q.; Yang, G.-Y. J. Solid State Chem. 2004, 177, 4648-4654.

4. (a) Salentine, C.G. Inorg. Chem. 1983, 22, 3920-3924; (b) Anderson, J.L.; Eyring, E.M.; Whittaker, M.P. J. Phys. Chem. 1964, 68, 1128-1132.

5. Beckett, M.A.; Coles, S.J.; Davies, R.A.; Horton, P.N.; Jones, C.L. Dalton Trans. 2015, 44, 7032-7040.

6. Schubert, D.M.; Knobler, C.B. Phys. Chem. Glasses: Eur. J. Glass Sci. Technol. B 2009, 50, 71-78.

7. Altahan, M.A.; Beckett, M.A.; Coles, S.J.; Horton, P.N. Inorg. Chem. 2015, 54, 412-414.

8. Altahan, M.A.; Beckett, M.A.; Coles, S.J.; Horton, P.N. Inorg. Chem. Commun. 2015, 59, 95-98.

9. Geue, R.J.; Hambley, T.W.; Harrowfield, J.M.; Sargeson, A.M.; Snow, M.R. J. Am. Chem. Soc. 1984, 106, 5478-5488.

10. Characterization data for $1: \mathrm{C}_{28} \mathrm{H}_{73.50} \mathrm{~B}_{3} \mathrm{Cl}_{5} \mathrm{Co}_{2} \mathrm{~N}_{16} \mathrm{O}_{19.75}$. Elem. Anal Calc: $\mathrm{C}, 26.3 ; \mathrm{H} 5.8 ; \mathrm{N}, 17.5$. Found: $\mathrm{C}$, 25.6; H 6.5; N, 16.7\%. Mp $285{ }^{\circ} \mathrm{C}$. TGA: - $4.75 \mathrm{H}_{2} \mathrm{O} 7.8 \%$ (6.7 \% calc.), - $2 \mathrm{H}_{2} \mathrm{O} 3.2 \%$ (2.8\% calc.), cation oxidation $57.7 \%$ (58.6\% calc.), residual $\mathrm{Co}_{2} \mathrm{~B}_{3} \mathrm{O}_{3} \mathrm{Cl}_{5} 31.3 \%$ (31.9\% calc). IR ( $\mathrm{KBr} / \mathrm{cm}^{-1}$ ): 3401(br,s), 3041(vs), 2871(vs), 1558(vs), 1432(m), 1345(s), 1077(m), 988(w), 849(w), 813(w). NMR (400 MHz, D $\left.{ }_{2} \mathrm{O}\right) \delta^{1} \mathrm{H} / \mathrm{ppm}$ : $3.776 \mathrm{H}(\mathrm{d}, 13.8 \mathrm{~Hz}), 3.416 \mathrm{H}(\mathrm{m}), 3.246 \mathrm{H}(\mathrm{d}, 13.8 \mathrm{~Hz}), 2.836 \mathrm{H}(\mathrm{m}) . \delta^{11} \mathrm{~B} / \mathrm{ppm}: 16.2 . \delta^{13} \mathrm{C} / \mathrm{ppm}: 87.8,55.1$, 51.4 .

11. Bernhardt, P.V.; Bygott, A.M.T.; Geue, R.J.; Hendrey, A.J.; Korybut-Daszkiewicz, B.R.; Lay, P.A.; Pladziewicz, J.R.; Sargeson, A.M.; Willis, A.C. Inorg. Chem. 1994, 33, 4553-4561.

12. (a) Wang, G.-M.; Sun, Y.-Q.; Yang, G.-Y. J. Solid State Chem. 2006, 179, 1545-1553; (b) Liu, Z.-H.; Zhang, J.J.; Zhang, W.-J. Inorg. Chim. Acta 2006, 359, 519-524; (c) Yang, Y.; Wang, Y.; Zhu, J.; Liu, R.-B.; Xu, J.; 
Phosphorus, Sulfur and Silicon, 190: xxxx-yyyy, 2015

Copyright $($ Taylor and Francis Group, LLC

ISSN: 1042-6507 print / 1563-5325 online

DOI: $10.1800 / 10426507.2015$

Meng, C.-C. Inorg. Chim. Acta 2011, 376, 401-407; (d) You, X.; Zhu, L.; Sun, J. Chin. J. Chem. 2010, 28, 2174-2178.

13. (a) Coles, S.J.; Gale, P.A. Chem. Sci. 2012, 3, 683-689; (b) Rigaku, CrystalClear-SM Expert 3.1 2013, b27; (c) Sheldrick, G.M. Acta Crystallogr. 2015, C71, 3; (d) Farrugia, L.J.; J. Appl. Crystallogr. 1997, 30, 564; (e) Palatinus, L.; Chapuis, G.; J. Appl. Crystallogr. 2007, 40, 786-790; (f) CrysAlisPro, Agilent Technologies, version 2014, 1.171.37.31.

14. A Rigaku AFC12 goniometer equipped with an enhanced sensitivity (HG) Saturn724+ detector mounted at the window of a FR-E+SuperBright molybdenum rotating anode generator with VHF Varimax optics $(70 \mu \mathrm{m}$ focus) was used. X-ray data for $\mathbf{1}$ : $\mathrm{C}_{28} \mathrm{H}_{73.50} \mathrm{~B}_{3} \mathrm{Cl}_{5} \mathrm{Co}_{2} \mathrm{~N}_{16} \mathrm{O}_{19.75}, \mathrm{M}=1278.06$; triclinic space group $P-1, a=$

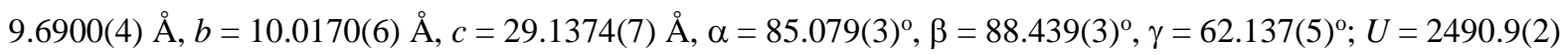
$\AA^{3} ; Z=2 ; T=100 \mathrm{~K} ;$ Wavelength $=0.71075 \AA$ A density (calc) $=1.704 \mathrm{Mg} / \mathrm{m}^{3} ;$ Absorption coefficient 1.024 $\mathrm{mm}^{-1}$; Crystal: orange lath, $0.180 \times 0.030 \times 0.010 \mathrm{~mm}^{3} ; F(000) 1331 ; \theta$ range for data collection 2.420-29.944 ${ }^{\circ}$; Index ranges $-13 \leq h \leq 12,-13 \leq k \leq 13,-38 \leq l \leq 40 ; 36914$ reflections collected with 12826 independent reflections $\left[R_{\text {int }}=0.0478\right]$; Completeness to $\theta=25.242^{\circ}, 99.9 \%$; absorption correction: semi-empirical from equivalents; refinement method: full-matrix least squares on $F^{2}$; data/restraints/parameters 12826/0/668; goodness-of-fit on $F^{2}, 1.023$; Final $R$ indices $\left[F^{2}>2 \sigma\left(F^{2}\right)\right] R 1=0.0485, w R 2=0.0976$; $R$ indices (all data) $R 1=$ $0.0740, w R 2=0.1072$; extinction coefficient $\mathrm{n} / \mathrm{a}$; largest diff. peak and hole 0.881 and $-0.662 \mathrm{e} \AA^{-3}$.

15. Achilleos, A.A.; Gahan, L.R.; Hambley, T.W.; Healy, P.C.; Weedon, D.M. Inorg. Chim. Acta 1989, 157, 209214.

16. (a) Negro, A.D.; Pozaz, J.M.M.; Ungaretti, L. Am. Mineral 1975, 60, 897-883; (b) Salentine, G.C.; Inorg. Chem. 1987, 26, 128-132; (c) Beckett, M.A.; Horton, P.N.; Hursthouse, M.B.; Timmis, J.L. RSC Adv. 2013, 3, 15185-15191; (d) Schubert, D.M.; Visi, M.Z.; Knobler, C.B. Inorg. Chem. 2008, 47, 2017-2023.

17. (a) Beckett, M.A.; Coles, S.J.; Light, M.E.; Fischer, L.; Stiefvater-Thomas, B.M.; Varma, K.S. Polyhedron 2006, 25, 1011-1016; Beckett, M.A.; Hibbs, D.E.; Hursthouse, M.B.; Owen, P.; Malik, K.M.A.; Varma, K.S. Main Group Chem. 1998, 2, 251-258; (c) Beckett, M.A.; Strickland, G.C.; Varma, K.S.; Hibbs, D.E.; Hursthouse, M.B.; Malik, K.M.A. J. Organomet. Chem. 1997, 535, 33-41.

Received xx yyyy 2015; accepted xx yyyy 2015

Acknowledgements: We thank the EPSRC for use of the NCS Service.

Address correspondence to Dr M.A. Beckett, School of Chemistry, Bangor University, Bangor, Gwynedd, UK.

Email: m.a.beckett@bangor.ac.uk

Electronic supplementary information (ESI) available. CCDC 1423520. This data can be obtained free of charge from the Cambridge Crystallographic Data Centre via www.ccdc.cam.ac.uk/data_request/cif. 
POLYborate ANIONS TEMPLATED BY METAL COMPLEXES 